\title{
IDENTIFICATION MANAGEMENT IN NigERIA: INNOVATIONS FOR FINANCIAL INCLUSION
}

\author{
MONYE OGOCHUKWU*
}

\begin{abstract}
About $41.6 \%$ of Nigerians have no access to formal financial services. Studies have shown that apart from factors such as distance to banks, financial illiteracy, irregular income, unemployment and complexity of account opening; lack of proof of identity documentation debars a significant number of persons from accessing finance. This work seeks to address the issue of proof of identity as a significant factor of financial exclusion in order to help citizens more easily fulfil mandatory Know-Your-Customer (KYC) checks as well as facilitate access to financial services including payments, savings, loans, pension and insurance.

Significantly, the goal of citizens' identification was entrenched as far back as 1984 in the International Declaration of Human Rights. Similarly, goal 16.9 of the United Nations Sustainable Development Goals (SDG) which envisions a legal identity for all by the year 2030 also mirrors this call. However, though the National Identification Management Commission (NIMC) was established in 2007 to oversee all matters of citizens' registration, only about 30 million Nigerians have been registered out of the total national population of approximately 198 million.

Using a doctrinal method of research, this work examines the reasons for the slow pace of registration by the commission and also attempts to offer solutions. This method of research is ideal as mostly legal literature and regulatory guidelines and policies are utilised in the analyses. Furthermore, the work draws examples from the regulatory landscape of jurisdictions such as Pakistan, Peru and India where positive strides have been achieved in the sphere of citizens' registration. In Pakistan for instance, 98 per cent of the target population have been captured by the national identification program including socially disadvantaged groups with the help of mobile registration agents comprising of hikers, van drivers, mountaineers, bikers, and skiers to locate citizens even in the most remote locations. ${ }^{1}$

The author proposes a self-sustaining universal national identification system that provides Nigerians with the needed foundational identity to access financial services with a view to achieving financial inclusion as well as other social services. The paper also proposes an efficient national identification system that is cost-effective, inclusive and recognises the limitations of some Nigerians especially persons without documentation and those residing at a distance from banks. In addition, the shortcomings of the existing identification system such as funding strategies, mode of registration and logistics management are
\end{abstract}

* Law Lecturer, University of Benin, Nigeria; PhD candidate, University of Cape Town, South Africa.

1. Leigh Anderson et al., ITU-T Focus Group Digital Financial Services: Review of NATIONAL IDENTITY Programs, 24 (May 2016). 
highlighted. Finally, a more effective means to reach excluded populations founded on emerging technology particularly digital identification using biometrics and associated technologies such as blockchains is suggested.

The paper is expected to contribute to the growing body of literature on improving national identification and to add some thoughts to the global conversation on financial inclusion bolstered on an effective national identification system. Furthermore, the recommendations are intended to foster socially inclusive gains in several other sectors beyond the financial sector including agriculture, health, and social security. Finally, even though this work is specifically focused on Nigeria, the findings offer veritable lessons for other nations grappling with financial exclusion by reason of inadequate or unsuitable identification systems.

This work is divided into 3 parts. Part I provides an overview of the national identification and financial inclusion efforts in Nigeria. Part II provides some insights into national identification in Nigeria while Part III highlights the value in developing a system based on biometrics and the positive link with financial inclusion.

Keywords/Phrases Financial inclusion, financial access, national identification

\section{INTRODUCTION}

\section{A. Description of Concepts}

\section{Financial Inclusion}

Financial inclusion is described by the Central Bank of Nigeria (CBN) as "enhancing access and usage of financial services at affordable costs to the vast majority of disadvantaged and vulnerable low income groups; it is the availability and accessibility of financial products and services to the entire population without discrimination." 2 The Centre for Financial Inclusion (CFI) also defines financial inclusion as "A state in which all people who can use them have access to a full suite of quality financial services, provided at affordable prices, in a convenient manner, and with dignity for the clients. Financial services are delivered by a range of providers, most of them private, and reach everyone who can use them, including disabled, poor, rural, and other excluded populations. ${ }^{3}$

Furthermore, the Financial Action Task Force (FATF) defines the term as:

providing access to an adequate range of safe, convenient and affordable financial services to disadvantaged and other vulnerable groups,

2. Central Bank of Nigeria, CPD FAQs, 3, https://www.cbn.gov.ng/Devfin/CPD_FAQs.pdf [https://perma.cc/U4M9-333F].

3. Centre for Financial Inclusion, Financial Inclusion Glossary (2018) https://www. centerforfinancialinclusion.org/financial-inclusion-glossary [https://perma.cc/4MR6-LFM7]. 
including low income, rural and undocumented persons, who have been underserved or excluded from the formal financial sector. ${ }^{4}$ It is also, on the other hand, about making a broader range of financial services available to individuals who currently only have access to basic financial products. ${ }^{5}$

Anti Money Laundering and Terrorist Financing Measures and Financial Inclusion, FATF Guidance, 12, (Feb. 2013).

\section{Legal Identity}

Legal identity is a composite condition obtained through birth or civil registration which gives a person an identity (name and nationality) and variables of unique personal identifiers, such as biometrics combined with a unique identity number. ${ }^{6}$ Identification provides a continuous, permanent, compulsory, and universal recording of the occurrence and characteristics of vital events including live births, deaths, fetal deaths, marriages, and divorces and other civil status events pertaining to the population.?

\section{Biometrics}

Biometrics refers to metrics related to human characteristics including, fingerprint, face recognition, palm veins, etc. ${ }^{8}$ Biometrics can also be defined as a measure of identity based on a physiological (fingerprint, face, eye iris or retina) or behavioural (speech or signature) characteristics. ${ }^{9}$ It is an effective personal identifier because it is unique to and embodied in each person, so it cannot be forgotten, lost or stolen like other conventional identification methods' ${ }^{10}$

\section{National Identification}

National identification embodies the collection of personal, proprietary and

4. Anti Money Laundering and Terrorist Financing Measures and Financial Inclusion, FATF GUIDANCE, 12, (Feb. 2013).

5. Id. at 12 .

6. Mia Harbitz and Bettina Boekle-Giuffrida, Democratic Governance, Citizenship, and Legal Identity: Linking Theoretical Discussion and Operational Reality, Inter-American Development Bank (May 2009) (working paper).

7. $I d$. at 5 .

8. Chenshan, and Rob Reeve, ITU-T Focus Group Digital Financial Services DFS Vendor Platform Features, 9 (Feb. 2017).

9. Xavier Giné et al., Use of biometric technology in developing countries, http://siteresources.worldbank.org/DEC/Resources/Policy_paper-biometrics.pdf [https://perma.cc/B7HE-SH8C].

10. Id. at 1 . 
transactional information such as name, address, location, date of birth, gender; biometrics information including iris scans, fingerprints, photo capture and physical credentials such as complexion and eye colour. ${ }^{11}$ Registration could be conducted onsite at designated registration centres or offsite on mobile registration vans, at the residence of citizens or in public places such as market squares, town halls, public schools and places of worship. Identification systems rely on three indices- something possessed by the individual (such as a card, token or other credential), something known (such as a password, PIN or ability to provide personal information) and something one is (such as physical biometrics e.g. photos and fingerprints or behavioural characteristics such as speech pattern). ${ }^{12}$

\section{B. The Value in Developing an Efficient National Identification Management Program}

An illiterate person is one who cannot write his name, and an illiterate state is one that cannot write the names of its citizens. ${ }^{13}$

Developing a national identification management program is crucial and holds many benefits. In the first place, a well managed national identification database provides reliable understanding of the different facets of a citizen's life from birth to death registration including health status, political affiliations, economic and social preferences. This data is important for evaluating the size, growth, economic and social dimensions, development indicators, and the characteristics of a country's population to effectively plan government policies and interventions. ${ }^{14}$ Additionally, a national ID provides a legal document for people to establish their legal identity, family relationships, and civil status, thereby facilitating participation in society. ${ }^{15}$ Also, national ID serves as a foundational piece of information upon which other entities in need of proof of identity can build on.

National identification ensures that citizens are able to assert civic, social, economic, and political rights and duties such as voting in elections, claiming government benefits, and opening bank accounts. This also creates a verifiable

11. See Leigh ANDERSON ET AL., supra note 1, at 13.

12. Alan Gelb and Anna Diofasi, Preliminary Discussion Paper on the Future of Identification and Development, (Oct. 31. 2015) (draft), https://www.cgdev.org/sites/default/ files/identification-development-what-have-we-learnt-and-where-are-we-going.pdf[https:// perma.cc/35BA-WZC2].

13. Plan Nacional Peru Contra la Indocumentacion 2011-2015. See also Leigh ANDERSON ET AL., supra note 1, at 7.

14. United Nations Department of Economic and Social Affairs, Get every one in the picture: Why is civil registration so important for statistics?, STATISTICS BRIEF, Issue No. 02, (November 2014), 1, http://getinthepicture.org/sites/default/files/resources/Stats_Brief_CRVS_Nov2014_Issue_ 02.pdf [https://perma.cc/Q7DE-L7MG].

15. Id. at 2 . 
legal identity for citizens and is useful for facilitating tax collection, enhancing the reliability of economic and financial transactions, and in the design of effective public policies. ${ }^{16}$

Furthermore, national identity systems help in crime fighting, prevention and detection as well as disaster recovery. In Pakistan for instance, data from the registration authority was used to uncover proxy prisoners serving sentences for the wealthy; reveal tax evasion and collusion with tax authorities, and to discover massive voter fraud resulting in the deletion of 37 million fake voters from the database. ${ }^{17}$ This database was also used to assist victims of the 2010 flooding in Pakistan by confirming street addresses with information held by the registration authority. ${ }^{18}$ Here, about 55 billion rupees $(\$ 586 \mathrm{~m}$; $£ 381 \mathrm{~m})$ in donor funds was disbursed to more than 2.4 million affected families to facilitate disaster response. ${ }^{19}$ Similarly this information has proved useful in identifying victims of suicide bombings and air crashes. ${ }^{20}$

The place of a national identity management system that facilitates the registration of all citizens and leads to the lessening of at least one burden borne by the excluded class towards attaining financial inclusion cannot therefore be over-emphasized. The following section outlines Nigeria's journey towards financial inclusion.

\section{Background to Financial Inclusion in Nigeria}

Nigeria's commitment to financial inclusion gained prominence in 2011 at the Maya Declaration organised by the Alliance for Financial Inclusion (AFI) comprising of about 100 national central banks and development organisations such as the World Bank. ${ }^{21}$ Nigeria, along with other nations, committed to improve financial inclusion by tackling peculiar country barriers that exclude citizens from financial access and reduce financial exclusion to 20 percent by the year 2020.

In line with the minimum targets set out in the declaration, Nigeria launched the National Financial Inclusion Strategy (NFIS) in 2012 and a technical and steering committee inaugurated in 2015 to monitor, review and execute country targets. $^{22}$ A secretariat has also been established to provide support for these

16. William Reuben and Flavia Carbonari, Identification as a National Priority: The Unique Case of Peru (Center for Global Development, Working Paper No. 454, 2017).

17. M Iilyas Khan, Pakistan's Experience with Identity Management, BBC News, (June 8, 2012), http://www.bbc.com/news/world-asia-18101385 [https://perma.cc/SGM7-MRCF]. See also Alan Gelb and Anna Diofasi, supra note 12, at 74.

18. See LeIGH ANDERSON ET AL, supra note 1, at 44 .

19. See M Ilyas Khan, supra note 17.

20. See M Ilyas Khan, supra note 17.

21. Alliance for Financial Inclusion, Maya Declarations: Commitments you can Bank on, http://www.afi-global.org/maya-declaration [https://perma.cc/6L3M-HKWM] (last visited Aug. 15, 2019).

22. Central Bank of Nigeria, Stakeholders Affirm Commitment to the National Financial 
committees, coordinate the activities of stakeholders towards implementation, and to gather and analyze data to inform the public on the progress made. ${ }^{23}$ Further, the Central Bank of Nigeria (CBN) has introduced the National Financial Literacy Framework (NFLF) in 2016 to aid client education on financial products and service offerings and the National Consumer Protection Framework to protect the rights of financial sector consumers. ${ }^{24}$

The CBN has also adopted a myriad of guidelines and regulations to advance digital financial inclusion including the Guidelines on Electronic Banking 2013, the Know-Your-Customer Guidelines 2013, the Guidelines on Agent Banking and Agent Banking Relations 2013, the 2014 Guidelines on Card Issuance, the Guidelines/Framework for Mobile Money Services in Nigeria 2015, the Nigeria Deposit Insurance Company Pass-through Guidelines 2015, the Guidelines on Operations of Electronic Transactions in Nigeria 2016 and the Guidelines on Transaction Switching 2016. The cashless initiative was also launched in 2012 to reduce cash dependency in Nigeria and foster the use of digital financial systems. Further, the Mcash was adopted to facilitate low value retail payments channels for financial consumers. ${ }^{25}$ The Guidelines on Payment Service Banks 2018 has been introduced to enable alternative providers such as Mobile Network Operators to offer limited financial services. A Collateral registry has also been established to facilitate access to credit by enabling the registration of security interests over assets that remain in the possession of borrowers.

Of all the initiatives adopted by the $\mathrm{CBN}$ to improve financial inclusion, the KYC guidelines stand out as the most valuable for dislodging the barrier of identification documentation for the financially excluded class. With the adoption of the guidelines, a tier-based bank account system was introduced for the first time in Nigeria, discarding the former regime of uniform account opening requirements. The next section examines the adoption and implementation of this initiative.

\section{Know-Your-Customer Guidelines 2013}

In 2013, the CBN adopted the KYC guidelines which essentially introduced a tiered account model enabling bank customers to open and operate one of three stratified accounts, depending on the type of identification documentation presented. A customer can opt for the low-value accounts, medium-value accounts or the high-value accounts. To open a low-value account, prospective

Inclusion Strategy Implementation, Financial Inclusion Newsletter Volume 1 Issue 1, 1 (Jan. 2016) https://www.cbn.gov.ng/Out/2016/CCD/JANUARY\%202016\%20Volume\%201,\%20Issue\%201 \%20Web.pdf [https://perma.cc/T5MG-Y6Z7].

23. CBN, Financial Inclusion, https://www.cbn.gov.ng/FinInc/default.asp [https://perma.cc/ 3KXB-TDDF] (last visited Aug. 15, 2019).

24. Id.

25. Mcash, About Mcash, https://www.mcash.com.ng/ [https://perma.cc/Q45Y-CZ2P] (last visited Aug. 15, 2019). See also Bank Verification Number, About, https://nibss-plc.com.ng/bvn/ [https://perma.cc/6Q82-8LZH] (last visited Aug. 15, 2019). 
customers only have to present basic information such as name, address gender, date/place of birth, passport and phone number without the need for additional verification. ${ }^{26}$ The medium-value account on the other hand requires the same information provided in the case of low-value clients in addition to one document evidencing identity and verified against records held by designated government agencies. These agencies include the National Identification Management Commission (NIMC), the Independent National Electoral Commission (INEC) and the Federal Road Safety Commission (FRCS). ${ }^{27}$

Even though these two accounts require minimal identification documentation to open and operate, the CBN places several limitations on the type, value, and volume of transactions applicable to these accounts. For low value accounts, it is prohibited to make single deposits exceeding N50, 000.00 or maintain a cumulative balance above N300, 000.00. Likewise, the CBN only permits a single deposit of N100, 000.00 and a cumulative balance of N500, 000.00 for medium value accounts. ${ }^{28}$ Again, only local transactions are permitted on these two accounts as transacting outside Nigeria is prohibited under the Guidelines. $^{29}$

Only the high-value account enables a customer to conduct full banking transactions without limitation. There is no maximum on single deposits or cumulative balance, or is there a restriction on geographical destinations. Thus, this account serves as the only fully functional account for the banked population..$^{30}$ However, obtaining this high-value account is not without conditions. To qualify for this account, consumers must undergo a complex onboarding process involving filling out personal and contact details, updating biometrics and presenting state-issued identification documentation required to prove customer identity.

A cumulative reading of the KYC Guidelines and the CBN Anti-money Laundering/ Counterfeiting of Terrorism Regulations 2013 lays down the specific state-issued identification documentation permitted for opening a high-value account. These include the INEC voter card, the National Identification Management Commission (NIMC) National Identification Number card (NIN card), international passport, driver's license, tax assessment slip, social security records and permanent residence permit bearing a photograph. ${ }^{31}$ The first four are

26. Central Bank of Nigeria, Anti-money Laundering and Combating the Financing of Terrorism in Banks and Other Financial Institutions in Nigeria Regulations (2013) 100:65 O.G., Reg. 45.

27. Id.

28. Review of Restrictions and Limits on Levels I and II of the Tiered KYC Accounts, CENTRAL BANK OF Nigeria, https://www.cbn.gov.ng/out/2016/fprd/july\%202016\%20circular\% 20tkyc\%20review.pdf [https://perma.cc/6KR6-NVVV] (last visited Aug. 15, 2018).

29. Introduction of Three-Tiered Know Your Customer (KYC) Requirements, CENTRAL BANK OF NigERIA, https://www.cbn.gov.ng/out/2013/ccd/3\%20tiered\%20kyc\%20requirements.pdf [https://perma.cc/XER6-K3AA] (last visited Aug. 15, 2019).

30. See Central Bank of Nigeria, supra note 26, at Reg. 45.

31. See Central Bank of Nigeria, supra note 26, at Reg. 50, 72, Sch. 2. 
however, the most popular.

Additionally, banks demand proof of address evidenced by utility bills from clients as an added layer of identification to open these high-value accounts. ${ }^{32}$ Aside from the inconvenience that this foists on the unbanked, the practice of insisting on proof of address evidenced by utility bills also ignores the exhortation of the CBN that banks need to employ a risk-based approach in the interest of financial and social inclusion objectives by accepting simpler documentation. ${ }^{33}$ The $\mathrm{CBN}$ recommends the use of documentation such as a letter or statement from a person in a position of authority including solicitors, doctors, teachers and ministers of religion who can confirm the identity and physical address of the client. ${ }^{34}$

The insistence on proof of address also fails to recognize that some clients reside in community settings where clan-based address system rather than the conventional street numbers are used. Insistence, therefore, on bills issued by specific utility companies such as the state-owned water corporations and state electricity distribution companies invariably excludes numerous rural consumers un-served by these entities. More so, physical identification documentation is prone to the risk of manipulation or forgery in addition to loss or destruction by disasters. Financial providers therefore need to consider a shift from this practice.

From the foregoing, it can be deduced that while tiered KYC was introduced to advance financial inclusion for the poor and other persons grappling with the hurdle of obtaining identification requirement, access to quality financial services, a core pillar of financial inclusion is not yet guaranteed on all tiers. In other words, customers without high-value accounts are unable to perform full financial transactions as only basic financial services such as savings and low-value transfers are permitted on the other two tiers.

\section{NATIONAL IDENTIFICATION MANAGEMENT IN NIGERIA}

\section{A. History of National Identification Management in Nigeria}

Historically, Nigeria has recorded some attempts at collecting the identity of citizens both at a governmental level and more specific private sector arrangements. For example some orthodox churches such as the Catholic and Anglican churches have been engaged in the recording of infant baptisms evidenced by the issuance of baptismal cards. Also, local government authorities have been known to conduct the registration of natives evidenced by local government identification documents mainly to indicate a person's state and local government of origin. The SIM registration mandated by the Nigerian Communications Commission (Registration of Telephone Subscribers)

32. See Central Bank of Nigeria, supra note 26, at Sch. 2. Besides the use of utility bills, this schedule additionally stipulates the use of tax assessment, letter from a person in authority and bank statements but utility bills remain the most requested documentation.

33. See Central Bank of Nigeria, supra note 26, at Reg. 48, 49, 73, 77.

34. See Central Bank of Nigeria, supra note 26 , at Reg. 48, 49, 73, 77. 
Regulations, 2011is yet another example of an identification database that has resulted in the collection of mobile phone users' data including name, address, occupation, facial capture and fingerprints of users. ${ }^{35}$ Government and private hospitals have also been engaged in the registration of births and issuance of birth certificates. The Independent National Electoral Commission (INEC), the electoral authority in Nigeria, also conducts voter registration for election purposes. The commission has succeeded in registering $84,004,084$ adult voters. ${ }^{36}$

These records are however neither comprehensive nor widely accepted as proof of identification. For example, a baptismal card is issued mainly to members of a specific religious denomination and is not an acceptable form of identification when opening a financial institution account. Similarly, local government identification databases only contain fragmented information covering natives of particular local government areas and accepted in selected transactions such as applications for the international passport. Likewise, birth certificates cannot be used to open accounts and hospital birth records scarcely cover babies delivered at home or in the unregistered centres of Traditional Birth Attendants (TBAs). Other examples include national health insurance registration and the pension scheme registration which pertain mainly to civil servants. Additionally, Bank Verification Numbers (BVN) only apply to bank clients and the driver's licence for car owners and drivers.

This fragmented and diversified approach to identity management is not only inefficientbut is also wasteful of scarce economic resources. In a bid to create a comprehensive and universally inclusive national identification database, the Nigerian government, in 2007, established the National Identification Management Corporation (NIMC) to constitute a comprehensive national identification database of citizens and permanent residents. With the collaboration of all the financial institutions in Nigeria, the Central Bank has also introduced compulsory biometrics registration as part of KYC compliance for all bank clients. The following section explores the efforts of these two entities in the sphere of ID registration.

\section{B. Registration by the National Identification Management Corporation (NIMC)}

After the 1978 attempt to register all NigerianS by the Department of National Civil Registration (DNCR) and subsequent enrolment by a private partner, the Federal Government constituted the National Identification Management Corporation (NIMC). This is the designated Federal Government authority vested with the mandate to facilitate the registration of all citizens and lawful residents in Nigeria in an authentic and verifiable national identity database. Established in 2007, the NIMC implements stated objectives using the

35. Nigerian Communications Commission (Registration of Telephone Subscribers) Regulations (2011) 98:101 O.G., Reg. 11, 19, 21.

36. Independent National Electoral Commission, INEC Nigeria, https://www.inecnigeria.org/ [https://perma.cc/5XQ2-7HMM] (last visited Aug. 15, 2019). 
NIMC Act 2007 and related regulations including the Mandatory Use of the National Identification Number Regulations, 2017, Nigeria Biometrics Standard Regulations, 2017, Registration of Persons and Contents of the National Identity Database Regulations, 2017, Access to Register Information in the National Identity Database Regulations, 2017; and Licensing of the Frontend Services of the NIMC Regulations, 2017. The commission manages the enrollment and issuance of the National Identification Number (NIN), the National e-ID card issuance, identity verification as well as data harmonization and authentication of user data. ${ }^{37}$

Specifically, the NIN is an eleven-digit number assigned upon de-duplication and enrolment into the National Identity database. ${ }^{38}$ This number ties together all records about a person including demographic data, fingerprints and other biometric data, head-to-shoulder facial picture and digital signature within the national identity database. ${ }^{39}$ Additionally, NIN registration entitles registered users to obtain a chip readable general multipurpose card useful for authenticating transactions, confirming the identity of an individual and provides the foundational information needed to establish functional identity. ${ }^{40}$

This number is issued for use for a non exhaustive list of activities relating to travel, bank accounts, driver's license, voting, national health insurance, taxes, pension, welfare and land transactions. ${ }^{41}$ Incidentally, the Act makes it an offence to perform any of these transactions without the NIN number. ${ }^{42}$ This offence is punishable with a fine of not less than N50, 000.00 or imprisonment for not less than 6 months for an individual offender and a fine of not less than N1, $000,000.00$ charged on a body corporate or an additional N1, 000, 000, 00 charged to the chief executive officer, line manager or any other officer deemed to be guilty in the case of a corporate offender. The commission presently has 805 enrolment centres across the 36 states of the Federation and the FCT and is currently active in 556 Local Government Areas (LGAs) but absent or dormant in 218 LGAs. $^{43}$ The NIMC also deploys mobile vans and sets up temporary

37. National Identification Management Commission (NIMC), Learn about the NIMC, https://www.nimc.gov.ng/ [https://perma.cc/EB4F-ALAG] (last visited Aug. 15, 2019)..

38. Mandatory Use of the National Identification Number Regulations (2015) 102:81 O.G., Reg. 3https://www.nimc.gov.ng/docs/MandatoryNIN_Gazetted.pdf [https://perma.cc/S6L4-LEZY].

39. National Identification Management Commission (NIMC), Why Your NIN is Important, https://www.nimc.gov.ng/nin-importance/ [https://perma.cc/ZN4F-ZT7M] (last visited Aug. 15, 2019).

40. See Mandatory Use of the National Identification Number Regulations, supra note 38, at Reg. $5,6,7$.

41. See Mandatory Use of the National Identification Number Regulations, supra note 38, at Reg.9.

42. See Mandatory Use of the National Identification Number Regulations, supra note 38, at Reg.13.

43. Emma Okonji, NIMC Registered 21.4 Million Nigerians in Five Years, THISDAYLIVE, (Sept. 13, 2017), https://www.thisdaylive.com/index.php/2017/09/13/nimc-registered-21-4-millionnigerians-in-five-years/ [https://perma.cc/V2AW-C49N]. 
registration centres in schools to reach citizens residing in remote areas. However, only about 30 million Nigerians have been registered since inception in $2007 .^{44}$

Worthy of note is the fact that the distance to registration centres is often significant for some persons as some states are shown from NIMC data to have just one registration centre per local government area (which can include several communities and a significant distance) and absent in others. ${ }^{45}$ Again, the repeat visits needed to register and collect cards can also be daunting. Typically, an applicant wishing to get registered must visit an NIMC designated centre at least three times to obtain the permanent General Multi-Purpose Card (GMPC). ${ }^{46}$ On the first visit, the customer receives a paper slip and is asked to return in about a week to collect the temporary voters' card after verification. The GMPC is scheduled for collection at an unspecified time 'when the customer is notified'. This waiting time can take a whole year. Although the NIMC registration service is free, a customer must pay a sum of N500.00 at a designated bank if collection is done at a venue different from the site of registration and in some centres, members of staff demand N200 to obtain the registration form. One can see how harrowing this process can be in terms of distance, cost and inconvenience especially for less well-off citizens. There is thus, an urgent need, to address the barriers that surround the commission's registration process.

For the poor, not owning an NIN card has financial inclusion implications especially since this is one of the four main documents required to open and operate a bank account in Nigeria. The other three are the voter card, the driver's license and the international passport. The voter card is relatively more accessible as a result of the campaign by politicians to garner votes during elections by lobbying for the establishment of registration centres in rural communities. However, the last two are more restricted and only pertain to persons who have cars or can drive and persons who travel or intend to travel abroad respectively. According to the Enhancing Financial Inclusion and Innovation in Nigeria report, about 6.9 per cent of Nigerians do not have accessto finance as a result of complexity of account opening and 4.2 per cent of Nigerians are debarred from accessing financial services as result of lack of identification documentation. ${ }^{47} \mathrm{On}$ the whole, the financial exclusion rate in Nigeria remains high at 41.6 per cent while rural exclusion rate stands at 77.7 per cent. ${ }^{48}$

44. 30 million Nigerians get National Identity Number, VANGUARD NewSPAPER, (Mar. 4, 2018), https://www.vanguardngr.com/2018/03/30-million-nigerians-get-national-identity-number/ [https://perma.cc/2Y5W-QY22].

45. NIMC, NIMC Enrolment Centres, https://www.nimc.gov.ng/nimc-enrolment-centres/ [https://perma.cc/RY9K-R56X] (last visited Aug. 15, 2019).

46. NIMC, How to Enroll (Adults) https://www.nimc.gov.ng/how-to-enrol-adults/ [https://perma.cc/F7KL-J7YS]

(last visited Aug. 15, 2019).

47. Enhancing Financial Innovation and Access (EFINA), Key Findings: EFInA Access to Financial Services in Nigeria (July 2017) 52, https://www.efina.org.ng/wp-content/uploads/2017/ 07/EFInA-Presentation-2-2.pdf [https://perma.cc/4YWB-CSSX].

48. Id. at 24 . 


\section{Registration under the Nigeria Inter-Bank Settlement System (NIBSS) - Bank Verification Number (BVN) Exercise}

The Bank Verification Number (BVN) exercise was launched by the CBN in 2014 in collaboration with all banks in Nigeria. The aim of this exercise is to assign a unique identity number to all bank users upon biometric identification, verification and authentication. Thus, in addition to physical identity documentation, banks are mandated by the $\mathrm{CBN}$ to conduct this registration exercise for all existing and prospective customers for accounts to be operative. Existing accounts for which no BVN have been assigned remain inoperable until rectified and new accounts only become operable upon completion of the mandatory biometrics registration. Even where accounts are opened offsite as in the case of code-enabled account opening services offered on banking apps and social media platforms, BVN registration is still needed to make these accounts operable. The BVN offers same day registration to Nigerians at home and in Diaspora. $^{49}$

Like the NIN, the BVN is an 11-digit unique transaction number assigned to every bank customer and verifiable across all banks in Nigeria. The unique BVN identifies and links all the financial transactions of customers irrespective of the number of banks and other financial institutions used. The number also serves the purpose of linking customer transactions across all financial institutions to create a verifiable digital audit trail to detect financial crimes. According to the $\mathrm{CBN}$, the BVN is expected to guard against unauthorised access, address identity theft, diminish exposure to fraud, reduce waiting time at the bank, and standardize efficiency of banking operations. ${ }^{50}$ Therefore, the practice of operating ghost and multiple accounts by one customer using different names is now impossible as only a consistent set of details verified with the use of biometrics is permitted for each customer.

While this project is laudable, a major limitation is that only customers within the financial sector are registered, therefore missing out the goal of universality. Significantly, about $39,778,181$ have been captured by the exercise as of November 2019. ${ }^{51}$ From a sector specific point of view therefore, success can be said to have been achieved. On a positive note however, the NIMC is harmonising and integrating the commissions' data with that of other agencies across Nigeria including the NIBSS BVN data with already evident results. ${ }^{52} \mathrm{In}$

49. NIBSS, Bank Verification Number:About, https://nibss-plc.com.ng/bvn/ [https://perma.cc/A6NS-YQAM] (last visited Aug. 15, 2019).

50. Id.

51. Id.

52. About the NIN, National Identity Management Commission (NIMC), https://www.nimc.gov.ng/about-nin/[https://perma.cc/LB63-VJBH] (last visited Aug. 6, 2019). See also Mandatory Use of Identification Number Regulations, 2015, 81 Federal Republic of Nigeria Official Gazette 102, 273 at 277-78 (May 15, 2015), https://www.nimc.gov.ng/docs/ MandatoryNIN_Gazetted.pdf[https://perma.cc/YV6N-HQEA]. 
four years of the harmonisation exercise, the number of registered persons has grown from 7 million in 2015 to 30 million as of $2017 .^{53}$

\section{Impact of National Identification Efforts on Financial Inclusion}

In spite of the foregoing efforts by the CBN towards improving financial inclusion and ensuring that consumers at the base of the pyramid obtain access to financial services, financial inclusion figures in Nigeria remain low. The NIBSS BVN number, though successful, only addresses some on-boarding concerns of the banked as stated above.

Section 1.4 above highlights that BVN is only requested as a supplementary to physical documentation during account opening but not as a standalone requirement. Although low-value accounts can be opened by presenting personal, contact details and biometrics without the need for documentation, limitations on thresholds in terms of value and volume of transactions as well as geographical restrictions diminish the quality of financial services offered to account holders.

Notably, 6.9per cent of Nigerians cite complexity of documentation in account opening and 4.2per cent of rural dwellers specifically cite the lack of identification documentation as a barrier to financial inclusion. ${ }^{54}$ This calls for more targeted efforts that consider the challenges of the excluded class. With the advancement in modern technology where biometrics features can be employed more meaningfully to achieve financial inclusion goals, continued insistence on physical documentation loses appeal.

Part III of this work therefore examines the use of biometrics as an alternative and not a supplementary metric of identification. The potential for ensuring universal financial inclusion using biometrics as a viable alternative to physical documentation is also highlighted.

\section{INNOVATIVE APPROACHES TO NATIONAL IDENTIFICATION REGISTRATION}

\section{A. Biometrics as an Authentic Alternative for Identification}

Biometrics is defined as "metrics related to human characteristics" including fingerprint, face recognition, palm veins, etc. ${ }^{55}$ This is also defined as "using measurements of human features, such as fingers or eyes in order to identify people." ${ }^{56}$ Some examples include fingerprints, iris scans and palm prints. Aside these popular features, medical breakthrough has broadened the range of biometrics to include physical and behavioural biometrics, such as vein patterns,

53. Emma Okonji, NIMC Registered 21.4 Million Nigerians in Five Years, ThisDaylive (Sept. 13, 2017), https:/www.thisdaylive.com/index.php/2017/09/13/nimc-registered-21-4-millionnigerians-in-five-years/ [https://perma.cc/R9CR-7EV2]. See also 30 million Nigerians get National Identity Number, supra note 44.

54. Key Findings: EFInA Access to Financial Services in Nigeria (A2F) 2016 Survey, supra note 47 .

55. Chenshan \& REEVE, supra note 8.

56. Biometrics, OXFORD ADVANCED LEARNER's DiCTIONARY(2019). 
lip movements, DNA, voice, smell, electrocardiogram (ECG), electroencephalogram (EEG), gait, dynamic signature and keystroke patterns. ${ }^{57}$

The value in using biometrics lies in the fact that every citizen possesses more than one of these features irrespective of age, geographical location and social status and thus provides inimitable and universally available metrics for the identification of all citizens. Biometrics therefore holds the potential for universal identification. Biometrics promotes authenticity of data subject as research has proven that even in the case of identical twins who share the same genetic expression, differences in specific biometrics such as fingerprints, iris and retina exist due to continually changing genetic information and environmental conditions including living style, diet and climate which occur with maturity ${ }^{58}$ For individuals, the iris of the eye is deemed a unique biometric feature in identical twins and is fully formed as early as the 8th month of gestation, remaining the same throughout life, while finger prints fully stabilise at around the age of $10 .^{59}$ In India, the unique Aadhaar ID number enables citizens to prove identity using iris scans or fingerprints across government and private entities entitling registered persons to easily assess subsidized food allocation, energy or fertiliser programs, pensions and scholarships ${ }^{60}$ The Aadhaar also allows citizens to fulfil KYC requirements needed to open bank accounts without the need to present physical documentation. ${ }^{61}$

The use of biometrics as an alternative for physical documentation as proposed in this work is often resisted by opponents who doubt the capacity of this system to adequately authenticate individual identity against an expansive database of citizens. This scepticism often comes from the fear of technological infallibility. Evidently, fingerprint scanners in Malawi have been tricked to accept reactivated latent prints or by using artificial fingers with forged fingerprints or dusting the sensor's platen with commercially available graphite powder and lifting with adhesive tape. ${ }^{62}$ Again research shows that artificial fingers made with

57. Gelb \& Diofasi, supra note 12 , at 47 .

58. Adams Kong, David Zhang \& Guangming Lu, A Study of Identical Twins' Palm prints for Personal Authentication 2,http:/www.ntu.edu.sg/home/adamskong/publication/Twin_ICBA_ 06.pdf[https://perma.cc/NB3Y-LKR7](last visited Aug. 7, 2019).

59. Frances Zelazny, The Evolution of India's UID Program Lessons Learned and Implications for Other Developing Countries, Center for Global Development 9, (2012), https://www.cgdev.org/publication/evolution-india's-uid-program-lessons-learned-andimplications-other-developing[https://perma.cc/7RFK-QYEU].

60. Alan Gelb \& Anna Diofasi Metz, Identification Revolution: Can Digital ID be Harnessed for Development? Center for Global Development1 (2018), https:/www.cgdev.org/ publication/identification-revolution-can-digital-id-be-harnessed-development [https://perma.cc/9N2Q-JFFE].

61. Id. at 1 .

62. Xavier Giné, et al., Use of biometric technology in developing countries, World Bank Research Committee, 10, 12, http://siteresources.worldbank.org/DEC/Resources/Policy_paperbiometrics.pdf [https://perma.cc/W47M-CG33](last visited Aug. 6, 2019). 
candle wax or gelatin have also successfully fooled the system. ${ }^{63}$

However, this should not lead nations to discard this technology. India presents a convincing example revealing a 0.057 per cent probability that an entry would be erroneously classified as a duplicate (a false positive) against the gallery of 84 million people. ${ }^{64}$

In recommending the use of biometrics, however, it is suggested that more than one metric of identification is needed to guarantee inimitability and ensure that everyone can present the required metric. This avails the registration authority the opportunity of obtaining credible and authentic data on more than one level from a subject. Also, users without one layer of required biometric can present others. For instance, while iris scans have the advantage of not being sight dependent and so usable for the blind, diseases such as cataracts can affect the eyes to the extent of making these ineffective for the purpose of identification. ${ }^{65}$ Similarly, fingerprints can be made ineffective by accidents (occasioning cuts or burns), extreme weight gain or loss, age (old age or new born) and medical conditions such as arthritis. ${ }^{66}$ Loss of fingers and skin pigmentation could also affect fingerprinting and can in rare cases be mistaken. ${ }^{67}$ Insisting therefore on only one metric of identification could be exclusionary.

In using biometrics, it is also important to consider the factor of cost. While some biometrics proves relatively easy and affordable to collect, others present significant cost. For instance, fingerprint scanners are relatively cheaper while collecting DNA samples of users or conducting a medical examination to determine vein patterns can be more cost-implicating. Again, while portable iris and fingerprint scanners can aid ambulatory registration services, vein patterns and DNA testing are best referred to laboratories which can slow down the registration process with the attendant risk of mixing up samples. Notably, the DNA is the only biometric that can be taken at birth and is stable over a lifetime, but rapid DNA assessment is still costly, not yet deployable on a mass scale and could take about an hour per individual to conduct. ${ }^{68}$

Best practices must be observed depending on the type of biometrics selected. Authors have suggested that care must be taken to eliminate ambient conditions, such as humidity for fingerprinting, reduction of excess light for facial capture and control of band-width, connection quality and language for voice recognition to achieve best results. ${ }^{69}$ It is expected that biometrics as an independent form of identification will grow in acceptance in Nigerian financial institutions to the greater aim of driving financial inclusion to persons debarred from accessing finance by reason of unavailability, complexity and inconvenience of procuring

63. Id. at 12 .

64. Alan Gelb \&Julia Clark, Identification for Development: The Biometrics Revolution, Center For Global Development 10 (Jan. 2013).

65. Zelazny, supra note 59.

66. Giné, et al.supra note 62 .

67. Id.

68. Gelb \& Clark, supra note 64 , at 11.

69. Gelb \& Diofasi, supra note 64, at 48. 
ID documentation.

\section{B. Setting Right the ID System in Nigeria: How Can Nigeria Advance Universality of Identification?}

The NIMC in Nigeria offers free identification registration services for all, but progress in registration has been slow and expensive. Since establishment in 2007, the commission has succeeded in registering about 30 million Nigerians. ${ }^{70}$ The place of a well-functioning national Identification system cannot therefore be over-overstated. The next section discusses some ideals that national regulators can adopt for getting right the ID system including emplacing universal registration as a national priority, ensuring privacy and data protection standards and adopting a self-sustaining and cost-effective registration strategy.

\section{National Identification as a National Priority}

In recognition of the social responsibility value and public good that can emanate from a comprehensive national identification system, it is important for the government and identification authorities to prioritise citizens' registration as a basic and essential right of citizens. Understanding this exercise as a priority will engender a more targeted reach on the part of the registration authority especially for low-income earners and persons residing in remote communities. Where necessary, massive awareness campaigns and programs should accompany registration associated with this class to foster widespread participation. Clearly, the gains from this exercise are obviously endless as citizens begin to participate more actively in societal life leading to a more robust democratisation.

\section{Address Cost Implications}

As much as seeking the proper identification of citizens should be a prerogative of the government in recognition of achievable benefits, it is also important to consider the funding required to make this a reality as well as developing cost-minimizing strategies. The NIMC must also consider the size and varying cost implications for providing registration services to different parts of Nigeria considering the populous size of 198 million and varying geographical characteristics. Again, the costs of employing ambulatory services must be factored in as well as the direct and indirect costs of free registration including the cost of enrolment, production and distribution of cards and staff training as well as the cost of transportation and payment of enrolment staff.

Costs can be reduced through strategic planning and elimination of administrative excesses such as duplication of registration, costly recording methods and efficient staffing to avoid waste. As observed in some jurisdictions, failing to put in place an efficient funding model has led to unnecessary delays

70. 30 million Nigerians get National Identity Number, supra note 44 . 
in addition to stalled or suspended programs especially where the national government provides the sole funding source as was witnessed in Malawi, Cambodia and Cote d'Ivoire. ${ }^{71}$

In contrast, countries such as Pakistan where significant strides have been achieved have succeeded in recouping a significant amount of investment by developing a cost effective and self-sustaining model rather than the traditional model of registering all citizens for free without the prospect of recouping any costs. Here, the registration authority NADRA was able to recoup some cost of enrolment and card production by imposing user data access fees to end-users such as financial institutions. ${ }^{72}$ Similarly, in Peru, the registration authorityRENIEC was able to devise a funding model that aided the self-reliant financing of the project to a large extent by leveraging on fees charged for related services including fees for the issuance of the DNI to persons older than 14, fees from issuing registry documents, civil status certificates and charges. ${ }^{73}$

Significantly, as the registration authority reaches the target population, costs for registration will begin to drop as witnessed in Peru and the authority can make innovative shifts to earn revenue. Here, following a drop in the registration as a result of attaining more than 98 per cent of the target population, the program was still able to survive on other business streams such as the provision of information, access to databases and certifications to third party users. ${ }^{74}$ The authority now offers identification verification and authentication services at a fee to private entities such as banks,mobile phone companies and notaries which represents about 34 per cent of self-generated revenues. ${ }^{75}$ Care must however be taken to ensure that consumers of these institutions are not foisted with these costs in the long run when accessing financial services.

Notably, NIMC can put citizens' data collected from this exercise to good use for numerous future transactions such as authentication and vetting services offered to financial services providers for KYC compliance, vetting of credit and loan applications and the grant of insurance and pension applications. Further, NIMC can generate additional streams of income from consultancy services offered to other countries and institutions grappling with identification registration or collecting customer data for similar projects. Citizens' data collected from this exercise can also be used for other future transactions such as authentication and vetting services offered to financial services providers for KYC compliance, vetting applications for credits and loans and for considering long-term financial products such as insurance and pension.

NIMC has indicated that e-ID cards will be issued at a fee by 2022; however, it is important for Nigeria to maintain free identification registration for all citizens as imposing charges could be prohibitive to some classes of persons such

71. See LeIGH ANDERSON ET AL., supra note 1, at 36.

72. Id.

73. Reuben \& Carbonari, supra note 16 , at 11.

74. Id. at 26 .

75. Id. at 31,32 . 
as the poor, persons residing in remote communities and rural women. ${ }^{76}$ Besides, additional fees such as travel costs and unpaid wages for hours spent outside of work are ordinarily borne by citizens and attempting to segment citizens into poor and well-off for the purpose of determining the class of persons to offer free services can amount to more administrative challenges, fraud and omission of persons most in need of identification. Moreover, this can cause persons in need of identification to bear the cost of registration at the expense of inclusion. ${ }^{77}$

\section{Build Capacity Around Identification Systems}

In terms of capacity building to improve efficiency of the identification system, regard must be had to the employment of competent staff, procurement of efficient registration tools and adoption of a well-planned system of registration. Considering the heterogeneous nature and cultural diversity of Nigeria, it is important to deploy members of staff that are versed in the local languages and civic mannerisms of the local people to ensure acceptance and facilitate registration. The NIMC must aim to meet all citizens as close to home as possible. This is necessary as citizens could put off getting registered where registration requirements prove daunting.

Technology innovations and tools such as portable computers, biometrics scanners, and data transmitters are indispensable to input information and speedily and safely transmit data to a central database. These are required to eliminate duplication of registration, forgery and identity theft. Further, digitisation ushers significant costsavings including the reduction of the number of registration staff, reduction in cost of paperwork, handling and transfer and greater efficiency of the system. Additionally, traditional and social media platforms are crucial to create widespread awareness and sensitisation about the importance of registration.

Technological tools deployed for registration exercise must be efficient and able to produce cards upon completion of the registration to eliminate repeat visits. Identification systems must also permit updating of citizens' details to reflect changing status including marital status, address and occupation, and age. Efficiency can be fostered by enabling electronic registration in real time. Pointof-service readers are also pertinent for authentication when required.

National ID registration can be further enhanced with the use of block-chains. This is basically a technology that enables real-time logging in of information and makes a record of all amendments to the information held on a database. Blockchains are ideal as all identity information relating to a client can be seen at a glance from birth to death and every other activity that occurs in between. This technology also removes incidences of duplications enables registration staff to purge double entries. Blockchains can assist in fraud detection and prevention

76. Dennis Erezi, Nigerians to pay for national ID card from 2022, says NIMC, The Guardian (Feb. 1 2019), THE GUARDIAN, https:/guardian.ng/news/nigeria/national/nigerians-to-pay-fornational-id-card-from-2022-says-nimc/ [https://perma.cc/L3ZU-TUYX].

77. Gelb \& Metz, supra note 60, at, page 2, 3 . 
as all additions and changes made to the system are preserved. Additionally, with the aid of blockchain technology, updates and harmonisation of data with other trusted and relevant authorities will become easier.

\section{Privacy and Data Protection}

The guarantee of the protection of data and privacy is important to ensure that citizens' data are not unfairly or unlawfully put to detrimental uses or transferred to unauthorised persons. Data standards such as limitation of use, disclosure of purpose and minimisation of collection must be maintained in identification registries. Registries acting as database controllers must adhere to strict standards of confidentiality in giving access to citizens' data containing highly sensitive personal information that could lead to personal security risks. Registration authorities must also ensure that all customer data are reliable, accurate and up to date and allow for amendment by clients where errors exist.

It is also crucial to ensure that databases do not open the opportunity for intrusive systems without regard to the nuggets of privacy. Regard must be had to information security, record safekeeping, ethical handling of personal information and the provision and management of Information Communications Technology. ${ }^{78}$ This can be achieved by instituting an effective national identification management system equipped with competent staff and vested with the legal authority to collect, process and protect personal data about citizens.

Furthermore, to advance the data protection and privacy of citizens, only basic required information should be visible and all other personal information provided in machine readable form to relevant entities. To this end, registration authorities must insist on segmenting personal information requested by third parties to ensure that only information required for a particular transaction is disclosed. For example, for SIM card registration, the credit information pertaining to a client is not necessary nor is the health status of a client required by a financial institution except in the case of life insurance applications. Importantly, the authorities must stipulate strict penalty for the violation of privacy of citizens and data protection standards. All these must be with the consent of data subjects. In India the Supreme Court ruled in 2012 that Unique Identification Authority of India (UIDAI), the registration authority, had no power to permit private or government entities to access the data of individuals without the consent of the individual. ${ }^{79}$

Further, fines charged to privacy offenders should benefit the victims of the infringement. Monetary compensation can be offered in the case of individuals and community development projects where infringement or privacy abuse

78. Mia Harbitz\& Bettina Boekle, Democratic Governance, Citizenship, and Legal Identity Linking Theoretical Discussion and Operational Reality, Inter-American Development Bank 38 (May 2009).

79. Shweta Banerjee, Aadhaar: Digital Inclusion and Public Services in India, World Bank Group 3 (Dec. 2015), http://pubdocs.worldbank.org/en/655801461250682317/WDR16-BPAadhaar-Paper-Banerjee.pdf [https://perma.cc/ENH5-DAJX]. 
affects a segment of the society. There is also the need for the authorities to put in place a channel for whistleblowing and reporting of incidents of abuse of privacy and data processing. These channels must enable anonymous reporting to protect the identity of the persons making disclosures.

5. Discard the Requirement for Utility Receipts as Proof of Address in Account Opening

As buttressed above in section 1.4, the insistence of financial institutions on the presentation of utility bills as proof of address can be exclusionary for consumers who are either un-served by selected utility companies or reside in clan-based communities without conventional address systems. A more universal system is therefore required to facilitate proof of address by consumers.

One such system is the What 3 Words system which essentially provides an address for everyone by dividing the world into grids of $3 \mathrm{~m} \times 3 \mathrm{~m}$ squares. By this system, every address is named by three common words such as ///mango.honey.sky meaning that no one is left without an address. On a positive note, this system has been accepted by the Nigerian Postal Service (NIPOST) and will hopefully be deployed by the banks in aid of persons without ID documentation. A similar solution is the SnooCode which originated in Ghana and is in use in Kenya, Gabon and Nepal is a free mobile app that generates a 6-7 digit alphanumeric code to identify a person's location and serve as an alternative address for persons without conventional state addresses.

\section{CONCLUSION}

This work explored the viability of introducing a self-sustaining and universal model of national identification that has the capacity to reach all Nigerians. The author proposed the use of biometrics to dislodge the barrier of proof of identity in aid of financial inclusion. This serves to remove the burden foisted on citizens by Know-Your-Customer requirements. Additionally, citizens will find it simpler to sign up for other social services. The work also suggests a self-sustaining model of registration that ensures that the registration authority recoups substantial costs of running the program and serves as an added revenue stream. The work also offered some suggestions for privacy, data protection, the use of biometrics and digitisation to facilitate more efficient data collection and management. 